OPEN ACCESS

ISSN 25482254 (online)

ISSN 20893833 (print)

Edited by:

Enik Setiyawati

Reviewedby:

Maria Waldetrudis Lidi

${ }^{*}$ Correspondence:

Noly Shofiyah

nolyshofiyah@umsida.ac.id

Received:6 Agustus 2020

Accepted: 11 Desember 2020

Published: 14 April 2021

Citation:

S. Noly (2021) A Misconception

Investigation of Ninth Grade

Students about Magnetism

Pedagogi

a: Jurnal Pendidikan. 10:1. doi:

10.21070/pedagogia.v10vi2i.781

\title{
A Misconception Investigation of Ninth Grade Students about Magnetism
}

\section{Investigasi Miskonsepsi Siswa Kelas IX Tentang Materi Kemagnetan}

Noly Shofiyah*

Pendidikan Ilmu Pengetahuan Alam, Universitas Muhammadiyah Sidoarjo, Indonesia

Misconception is an idea of understanding that is inconsistent with scientific ideas. This study aimed to identify the ninth grade students' misconceptions related to magnetism topic. For this purpose, an instrument consisting of two phases (two-tier) with fourteen multiple choice items on magnetism concepts was developed by the researcher. The diagnostic test was given to thirty-two ninth grade students. The findings indicated that 9th grade students experience misconceptions about the concept of magnetism including how to make and determine artificial magnetic poles, Lorentz force and GGL Induction. The results of this study can be used by teachers and researchers to choose substantial learning strategies for teaching magnetism material.

\section{Keywords: Misconception; Magnetism}

Miskonsepsi merupakan suatu gagasan tentang pemahaman yang tidak konsisten dengan gagasan ilmiah. Penelitian ini dilakukan untuk mengidentifikasi miskonsepsi siswa kelas IX terkait dengan materi kemagnetan. Untuk tujuan tersebut, sebuah instrument terdiri dari dua fase (two-tier) dengan 14 item soal pilihan ganda pada materi kemagnetan dikembangkan oleh peneliti. Tes diagnostic tersebut diberikan kepada tiga puluh dua siswa kelas IX. Temuan menunjukkan bahwa siswa kelas IX mengalami miskonsepsi tentang konsep kemagentan diantaranya yaitu sifat kemagnetan, cara membuat dan menentukan kutub magnet buatan, gaya Lorentz dan GGL Induksi. Hasil penelitian ini dapat digunakan oleh para guru dan peneliti untuk memilih strategi pembelajaran yang substansial untuk mengajarkan materi kemagnetan.

\footnotetext{
Kata Kunci: Miskonsepsi; Kemagnetan
} 


\section{PENDAHULUAN}

Banyak penelitian telah dilakukan untuk mengidentifikasi tentang ide-ide siswa dalam menjelaskan fenomena IPA. Duit et al. (2003) menyatakan bahwa, mayoritas siswa datang ke kelas IPA dengan pengetahuan atau keyakinan tentang fenomena yang akan diajarkan dan banyak siswa hanya mengembangkan pemahaman konsep sains yang terbatas setelah pembelajaran. Pengetahuan sebelumnya ini disebut prakonsepsi. Beberapa prakonsepsi siswa tersebut tidak sesuai dengan pandangan atau pendapat dari ilmuwan. Konsep awal yang tidak sesuai dengan konsep ilmiah disebut sebagai miskonsepsi atau salah konsep. Studi tentang miskonsepsi telah menjadi pusat isu dalam dunia pendidikan khususnya Ilmu Pengetahuan Alam (IPA). Miskonsepsi ini mempengaruhi pembelajaran siswa, karena mereka menafsirkan pengajaran guru dalam konsep yang yang salah. Oleh karena itu, penting untuk mengetahui miskonsepsimiskonsepsi siswa dan penyebabnya serta mengembangkan metode atau strategi mengajar untuk mengatasi miskonsepsi siswa.

Miskonsepsi sebagian besar bersumber dari pengalaman siswa sehari-hari. Miskonsepsi diperoleh dari pengalaman belajar sehari-hari maupun proses pembelajaran sebelumnya dan sangat menggangu pembelajaran selanjutnya sehingga perlu diperbaiki. Kesalahan konsep atau miskonsepsi IPA dapat berasal dari kesalahan pemahaman siswa sendiri, kesalahan pemahaman bahan ajar yang disampaikan guru, atau interaksi antara siswa dengan buku pegangan. Rendahnya pemahaman konsep pada siswa dikarenan pembelajaran lebih berorientasi pada mengingat dan menyelesaikan soal-soal. Miskonsepsi juga terjadi karena sumber belajar misalkan buku-buku pelajaran atau website yang salah. Banyak penelitian yang telah dilakukan untuk menemukan miskonsepsi siswa dan kesulitan belajar. Miskonsepsi siswa tersebut antra lain pada topik pembelajaran kelarutan, listrik, fotosintesis-respirasi, difusi, osmosis, system tata surya dll, Nabilah et al. (2013); Hesti et al. (2017); Cañal (1999); Kramer et al. (2012); Mellu et al. (2020). Wahid et al. (2011) mengidentifikasi tingkat pemahaman siswa dan miskonsepsi siswa tentang hukum gerak Newton, usaha, gaya dan energi pada siswa kelas VIII dengan menggunakan CRI (Certainty of Response Index).

Selain materi-materi yang telah disebutkan sebelumnya, Upayogi et al. (2019) juga melakukan penelitian tentang miskonsepsi pada topik Listrik dan Magnet siswa SMP kelas IX dan hasilnya menunjukkan bahwa siswa-siswa mempunyai masalah dalam memahami konsep kemagnetan. Hasil penelitian tersebut menyatakan bahwa siswa menganggap logam yang digosok ke magnet akan memiliki kutub yang sama dengan kutub magnet penggosok. Selain itu, siswa juga beranggapan bahwa kutub logam dan magnet yang didekatkan akan sejenis saat membuat magnet dengan metode induksi. Siswa tidak memahami bahwa selain jumlah lilitan, faktor yang mempengaruhi besarnya GGL Induksi adalah arah garis gaya magnet dalam kumparan dan arah lilitan kawat pada kumparan. Siswa menganggap bahwa ggl induksi dapat ditimbulkan saat magnet di luar kumparan sehingga jumlah garis gaya magnet yang melingkupi kumparan berkurang. Dengan kata lain, pada materi kemagnetan, siswa kurang memahami konsep tentang cara pembuatan magnet dan menentukan kutub-kutub magnet, serta menjelaskan faktor yang mempengaruhi GGL induksi. Yilmaz et al. (2012) dalam penelitiannya pada 60 siswa yang mengikuti pembelajaran jarak jauh di Turki pada materi elektromagnet menjelaskan bahwa terdapat tujuh miskonsepsi yaitu konsep magnet, medan magnet, kutub magnet, muatan partikel pada medan magnet, medan magnet pada sebuah kawat, sifat maghet suatu benda, dan konsep tentang pengaruh arah medan magnet terhadap arah arus listrik.

Selain itu, Silvina et al. (2017) melakukan penelitian untuk mengidentifikasi miskonsepsi siswa kelas $\mathrm{X}$ pada materi magnet dan ditemukan bentuk miskonsepsi siswa yaitu : 1) semua benda yang berwarna perak ditarik oleh magnet; 2) Magnet yang lebih besar memiliki tarikan yang lebih kuat daripada magnet yang lebih kecil; dan 3) semua logam dapat ditarik magnet. Setyaningsih et al. (2018) menggunakan soal tes diagnostik miskonsepsi tentang konsep medan magnet yang diberikan pada siswa SMA kelas XII IPA. Hasil penelitian tersebut menunjukkan bahwa siswa mengalami miskonsepsi mengenai konsep gaya pada partikel bermuatan dalam medan magnet, medan magnet pada kawat lurus berarus, medan magnet pada pusat kawat melingkar, medan magnet pada kawat sejajar berarus, gaya Lorentz pada muatan yang bergerak, medan magnet di sekitar kawat melingkar berarus, gaya magnet pada kawat sejajar berarus, penerapan konsep magnet, medan magnet di ujung solenoid, gaya Lorentz pada kawat lurus berarus, medan magnet di pusat solenoid, dan medan magnet pada toroid.

Meskipun ada sejumlah penelitian yang dilakukan untuk menyelidiki miskonsepsi siswa di berbagai bidang topik IPA, namun sedikit yang melakukan penelitian tentang miskonsepsi siswa Sekolah Menengah Pertama (SMP) pada materi Kemagnetan. Penelitian tentang miskonsepsi topik kemagnetan pada siswa SMP dilakukan oleh Upayogi et al. (2019), namun indikator-indikator yang diujikan terbatas pada konsep cara membuat magnet dan menentukan kutub-kutub magnet serta faktor yang mempengaruhi GGL Induksi. Oleh karena itu, dalam penelitian ini kami bertujuan untuk mengidentifikasi miskonsepsi siswa kelas IX pada topik kemagnetan dengan indikator: 1) menjelaskan pengertian magnet; 2) menjelaskan sifat-sifat magnet; 3) menjelaskan sifat-sifat magnet bahan; 4) menjelaskan cara membuat magnet dan menentukan kutub-kutub magnet; 5) menjelaskan konsep kemagnetan bumi; 6) menjelaskan konsep induksi elektromagnetik; 7) menjelaskan konsep GGL Induksi; dan 8) menjelaskan konsep gaya Lorentz. Adapun pertanyaan penelitian dalam studi ini adalah: "Miskonsepsi seperti apa yang dimiliki siswa kelas IX pada topik Kemagnetan?" 


\section{METODE}

Tujuan dari penelitian ini adalah untuk mengidentifikasi miskonsepsi siswa kelas IX pada materi kemagnetan. Untuk tujuan tersebut, sebuah instrument atau tes diagnostic dalam bentuk 14 butir soal pilihan ganda disusun oleh peneliti. Soal pilihan ganda dipilih karena bisa diberikan kepada sejumlah siswa dengan mudah, penilainnya bersifat objektif, dan hasilnya mudah dianalisis. Namun, karena soal pilihan ganda tersebut tidak mampu mengidentifikasi jawaban siswa secara mendalam, maka penelitian menggunakan bentuk tes diagnostic two-tier. Tier pertama merupkan pertanyaan konsep yang diberikan dalam bentuk pilihan ganda yang terdiri dari empat pilihan jawaban. Tier kedua, siswa diminta untuk menjelaskan sejauh mana tingkat keyakinan pada jawaban yan dipilih pada Tier pertama. Pada Tier kedua, siswa diberikan dua pilihan jawaban, yaitu "Yakin" dan "Tidak Yakin"

\section{[Figure 1 about here.]}

Tes diagnostic two-tier yang telah disusun kemudian divalidasi konstruknya oleh Ahli dalam hal ini apakah butir pertanyaan sudah sesuai dengan indikator. Hasil validasi menunjukkan bahwa tes diagnostik layak untuk digunakan. Tes two-tier tersebut kemudian diberikan kepada responden yaitu siswa kelas IX di sebuah SMP Muhammadiyah di Sidoarjo. Populasi dari penelitian ini adalah seluruh siswa kelas IX yang berjumlah 156 siswa. Sedangkan sampel nya berjumlah 32 siswa. Sampel dipilih melalui metode convenient sampling yaitu jenis pengambilan sampel nonprobability di mana sampel diambil dari sekelompok orang yang mudah dihubungi atau dijangkau.

Hasil tes diagnostic two-tier kemudian dianalisis dan dikategorikan berdasarakan kemungkinan pola jawaban siswa. Kemungkinan pola jawaban siswa dan kategorinya dapat dilihat pada Tabel $\mathbf{1}$.

\section{[Table 1 about here.]}

\section{HASIL DAN PEMBAHASAN}

Data hasil analisis miskonsepsi siswa pada materi kemagnetan berdasarkan kategori pola kemungkinan jawaban siswa pada Tabel 1, disajikan pada Tabel 2. Berdasarkan data pada Tabel 2, secara keseluruhan rata-rata siswa kelas IX memahami konsep tentang kemagnetan sebesar $23 \%$, mengalami miskonsepsi $60 \%$, dan tidak memahami konsep $17 \%$. Berdasarkan data tersebut, diketahui bahwa siswa kelas IX masih banyak yang mengalami miskonsepsi tentang materi kemagnetan.

Berdasarkan Tabel 2 juga, diketahui jumlah prosentase siswa yang paham konsep, miskonsepsi, dan tidak paham konsep berdasarkan indikator pembelajaran. Pada indikator 1 , prosentase siswa yang mengalami miskonsepsi sebanyak $66,8 \%$. Berdasarkan pilihan jawaban dan keyakinan siswa, mengindikasikan bahwa siswa meyakini sebuah magnet adalah logam besi yang hanya dapat menarik benda yang terbuat dari besi. Hal ini tidak sesuai dengan konsep yang sebenarnya bahwa magnet merupakan suatu jenis logam yang dapat menarik benda-benda lain yang terbuat dari logam tertentu.Tabel 2

\section{[Table 2 about here.]}

Pada Indikator 2, prosentase siswa yang mengalami miskonsepsi adalah 71,5\%. Secara teori, magnet mempunyai sifat dapat menarik benda-benda tertentu jika benda tersebut berada dalam jangkaunnya yaitu daerah di sekitar magnet yang dipengaruhi oleh magnet yang disebut medan magnet. Kekuatan medan magnet terbesar terletak pada ujung-ujung magnet tersebut. Namun berdasarkan hasil tes diagnostic, siswa meyakini bahwa jika sejumlah jarum pentul didekatkan pada sebuah magnet, maka jarum pentul menempel secara merata pada permukaan magnet. Dengan kata lain, siswa menganggap bahwa besar medan magnet sama merata di seluruh permukaan magnet.

Indikator 3 menguji pemahaman siswa tentang sifat-sifat magnet bahan. Sifat-sifat magnet bahan ada tiga jenis yaitu ferromagnetic, paramagnetic, dan diamagnetic. Sehingga pada indikator 3 ini terdapat tiga buah pertanyaan. Hasilnya menunjukkan bahwa prosentase siswa yang mengalami miskonsepsi $34,9 \%$. Prosentase tersebut terbilang cukup rendah jika dibandingkan dengan prosentase pada indikator pembelajaran lainnya. Dari tiga pertanyaan tentang sifat magnet bahan ferromagnetic, paramagnetic, dan diamagnetic, siswa paling banyak mengalami miskonsepsi dalam memahami kosep sifat bahan paramagnetic dan diamagnetic. Mayoritas siswa masih tidak meyakini tentang karakteristik dari sifat bahan paramagnetic dan diamagnetic, sehingga ketika diberikan pertanyaan dalam konteks yang berbeda, jawaban siswa tidak konsisten.

Untuk indikator 4, pertanyaan-pertanyaan dibuat untuk mengidentifikasi pemahaman siswa tentang cara membuat magnet dan menentukan kutub-kutub magnet. Hasil analisis menunjukkan bahwa prosentase siswa yang mengalami miskonsepsi 57,3\%, memahami konsep 25,3\%, sedangkan $17,4 \%$ siswa tidak memahami konsep cara membuat magnet dan menentukan kutub-kutub magnet. Hasil jawaban siswa menunjukkan bahwa siswa tidak yakin ketika mereka diminta untuk menentukan kutub-kutub magnet yang dihasilkan melalui pembuatan magnet dengan cara menggosok. Selain itu, siswa juga mengalami miskonsepsi ketika diminta untuk membedakan cara membuat magnet dengan induksi atau induksi elektromagnetik.

Soal nomor 9 dan 10 dengan indikator 5 berisi pertanyaan tentang konsep kemagnetan bumi. Secara teori, bumi merupakan sebuah magnet besar dengan kutub selatan magnet terletak di dekat kutub utara bumi, sedangkan kutub utara magnet terletak pada kutub selatan bumi. Namun, hasil tes diagnostic menunjukkan bahwa 64,3 \% siswa mengalami miskonsepi pada teori tentang kemagnetan bumi. Siswa cenderung beranggapan bahwa kutub utara magnet bumi berada di sekitar kutub utara bumi, dan kutub selatan magnet bumi berada di sekitar kutub selatan bumi.

Indikator 6 menguji pemahaman siswa tentang konsep 
induksi elektromagnetik. Induksi elektromagnetik merupakan peristiwa timbulnya arus listrik karena adanya perubahan medan magnet yang menghasilkan perubahan fluks magentik. Berbeda dengan definisi dari Induksi magnet. Induksi magnet adalah peristiwa timbulnya medan magnet karena adanya arus listrik. Namun, hasil tes diagnostic menunjukkan bahwa 71,6 \% siswa meyakini bahwa induksi elektromagnetik adalah medan magnet yang ditimbulkan oleh arus listrik. Dengan kata lain, siswa belum memahami tentang perbedaan antara induksi elektromagnetik dan induksi magnet.

Pada indikator 7, prosentase siswa yang mengalami miskonsepsi sebanyak 66,8 \%. Indikator 7 ini menguji pemahaman siswa tentang GGL Induksi. Hasil tes diagnostic mengindikasikan bahwa siswa meyakini GGL induksi dapat terjadi jika magnet berada di dalam kumparan atau di luar kumparan. Sedangkan, salah satu faktor yang mempengaruhi GGL induksi adalah arah lilitan kawat pada kumparan. Pemahaman tersebut tidak sesuai dengan teori. Menurut percobaan Faraday, arus listrik dapat dihasilkan dengan cara menggerakkan magnet batang keluar masuk kumparan Tipler (2008). Selain itu, besarnya GGL induksi ini bergantung pada banyaknya lilitan kumparan, kekuatan magnet, dan kecepatan perubahan medan magnet.

Indikator 8 memeriksa pemahaman siswa tentang konsep gaya Lorentz. Pada indikator ini, siswa diminta untuk memilih pernyataan yang sesuai tentang gaya Lorentz. Hasil analisis menunjukkan bahwa 47,7 \% siswa meyakini bahwa gaya Lorentz merupakan gaya tarik antar magnet yang satu dengan magnet yang lain dalam medan magnet. Sedangkan 47,6 \% siswa menganggap bahwa gaya Lorentz adalah gaya yang ditimbulkan akibat dari gaya tarik menarik antar magnet dalam medan magnet. Hasil tersebut mengindikasikan bahwa hampir separuh siswa telah memahami konsep tentang gaya Lorentz.

Beberapa miskonsepsi yang muncul dalam penelitian ini menunjukkan perlunya diselidiki penyebab timbulnya miskonsepsi tersebut secara khusus apakah berasal dari guru, strategi mengajar, bahasa, atau sumber belajar. Ramadhan et.al (2019) dalam penelitiannya menjelaskan bahwa sumber miskonsepsi pada materi medan magnetic adalah dari siswa itu sendiri. Bersumber dari pengetahuan awal siswa yang kurang dimana siswa-siswa tersebut mendapatkan pengetahuan dari temannya saat belajar bersama, membaca buku, melihat pembahasan soal di internet dan dari hasil praktikum yang tidak mendapatkan klarifikasi dari guru. Oleh karena itu, penting bagi guru untuk mengetahui konsep awal yang dipahami oleh siswa. Selain itu, Turgut et.al (2011) menambahkan bahwa guru IPA perlu diperingatkan tentang miskonsepsi yang disebabkan oleh penggunaan bahasa dalam mengajar dan membuat bahan ajar atau modul. Karena hal-hal tersebut merupakan sumber-sumber penyebab terjadinya miskonsepsi pada siswa.

Sebagai tambahan, setelah mengidentifikasi miskonsepsi, seorang guru juga dapat lebih mudah membimbing siswa untuk menemukan konsepsi ilmiah yang dapat diterima dengan meningkatkan strategi pengajaran. Miskonsepsi yang terdeteksi oleh penelitian ini dapat bermanfaat bagi guru dan pengembang kurikulum untuk merancang instruksi pembelajaran IPA yang efektif. Supaya pembelajaran IPA menjadi bermakna, maka guru perlu meremidiasi miskonsepsi yang dialami siswa dengan beberapa model dan metode pengajaran yang berbeda seperti, metode pembelajaran kooperatif Yolanda (2017), penemuan terbimbing Thohir et al. (2017), eksperimen Zulvita et al. (2017), peta konsep Utami et al. (2014), pendekatan konflik kognitif Maulana (2010), berdasarkan pada model perubahan konseptual. Selain itu, guru juga dapat mengembangkan bahan ajar yang sesuai dengan miskonsepsi yang dialami oleh siswa Pasaribu et al. (2017)

\section{KESIMPULAN}

Berdasarkan hasil temuan secara kuantitatif dari penelitian ini, dapat disimpulkan bahwa siswa kelas IX yang berpartisipasi dalam penelitian memiliki miskonsepsi tentang konsep kemagnetan. Sebanyak 66,8 \% siswa mengalami miskonsepsi tentang definsi magnet dan konsep GGL induksi. Selanjutnya, 71,5 \% siswa mengalami miskonsepsi tentang sifat-sifat magnet dan konsep induksi elektromganteik. Sebanyak 64,3\% dan 57,3\% siswa mengalami miskonsepsi masing-masing tentang konsep kemagnetan bumi, cara membuat magnet dan menentukan kutub-kutub magnet buatan. Prosentase siswa yang mengalami miskonsepsi dalam kategori rendah yaitu 47,6 \% dan 34,9\% terdapat pada indikator menjelaksan sifat-sifat bahan dan konsep gaya Lorentz.

\section{REFERENCES}

Cañal, P. (1999). Photosynthesis and'inverse respiration'in plants: an inevitable misconception?. International Journal of Science Education, 21(4), 363-371.

Duit, R. and Treaguat, D. F. (2003). Conceptual change: a powerful framework for improving science teaching and learning. International Journal of Science education, 25(6), 671-688

Hesti, R., Maknun, J., \& Feranie, S. (2017). Text Based Analogy in Overcoming Student Misconception on Simple Electricity Circuit Material. JPhCS, 895(1), 012146.

Kramer, E. M., \& Myers, D. R. (2012). Five popular misconceptions about osmosis. American Journal of Physics, 80(8), 694-699.

Maulana, P. (2010). Usaha Mengurangi Terjadinya Miskonsepsi Fisika Melalui Pembelajaran dengan Pendekatan Konflik Kognitif. Jurnal Pendidikan Fisika Indonesia, 6(2).

Mellu, R. N. K., \& Baok, D. T. (2020). Identifying Physics Teachers Candidate Misconception on Electricity, Magnetism, and Solar System. JIPF (Jurnal Ilmu Pendidikan Fisika), 5(3).

Nabilah, N., Andayani, Y., \& Laksmiwati, D. (2013). Analisis Tingkat Pemahaman Konsep Siswa Kelas XI IPA Sman 3 Mataram Menggunakan One Tier Dan Two Tier Test Materi Kelarutan Dan Hasil Kali Kelarutan. Jurnal Pijar MIPA, 8(2).

Pasaribu, A., \& Saparini, S. (2017). PENGEMBANGAN BAHAN AJAR BERBASIS KONTEKSTUAL UNTUK MEREMIDIASI MISKONSEPSI PADA MATERI GAYA DAN HUKUM NEWTON TENTANG GERAK. Jurnal Inovasi Dan Pembelajaran Fisika, 4(1), 36-48.

Ramadhan, D., Bobby, I., Ashnam, M., Alfianda, R., Marpaung, M. A., \& Sugihartono, I. (2019, December). STUDI MISKONSEPSI MEDAN MAGNETIK MENGGUNAKAN METODE FOUR TIER TEST UNTUK SISWA SMA KELAS XII. In PROSIDING SEMINAR NASIONAL FISIKA (E-JOURNAL) (Vol. 8, pp. SNF2019-PE).

Setyaningsih, E., Harijanto, A., \& Prastowo, S. H. B. (2018). Identifikasi miskonsepsi materi medan magnet menggunakan three tier test pada siswa kelas XII SMA di Jember. FKIP e-PROCEEDING, 3(1), 167-172.

Silviani, R., Muliyani, R., \& Kurniawan, Y. (2017). Penerapan Three Tier-Test untuk Identifikasi Kuantitas Siswa yang Miskonsepsi pada Materi Magnet. 
JIPF (Jurnal Ilmu Pendidikan Fisika), 2(1), 10-11.

Thohir, M. A., Wasis, W., \& Sugimin, W. W. (2017). Peningkatan Keterampilan Berpikir Kritis melalui Pembelajaran Metode Penemuan Terbimbing dalam Upaya Remediasi Miskonsepsi Materi Listrik Dinamis. JPPS (Jurnal Penelitian Pendidikan Sains), 1(2), 62-67.

Turgut, Ü., Gürbüz, F., \& Turgut, G. (2011). An investigation 10th grade students' misconceptions about electric current. Procedia-Social and Behavioral Sciences, 15, 1965-1971.

Upayogi, I. N. T., \& Juliawan, I. W. (2019). Reduksi Miskonsepsi Melalui Pembelajaran Berbasis Virtual Lab. Journal of Teaching and Learning Physics, 4(2), 45-53.

Utami, R., Djudin, T., \& Arsyid, S. B. (2014). Remediasi Miskonsepsi pada Fluida Statis Melalui Model Pembelajaran TGT Berbantuan Mind Mapping di SMA (Doctoral dissertation, Tanjungpura University).

Utami, R. D., Agung, S., \& Bahriah, E. S. (2017, May). Analisis Pengaruh Gender Terhadap Miskonsepsi Siswa Sman Di Kota Depok Dengan Menggunakan Tes Diagnostik Two-Tier. In Prosiding Seminar Nasional Pendidikan FKIP (Vol. 1, No. 2).

Wahid, H., \& Ihsan, N. (2011). Identifikasi Miskonsepsi Materi Usaha, Gaya Dan Energi Dengan Menggunakan CRI (Certainty of Response Index) Pada Siswa Kelas VIII SMPN 1 Malangke Barat. Jurnal Sains dan Pendidikan Fisika, 7(1).

Yilmaz, O., \& Ince, E. (2012). The Usage of Alternative Assessment Techniques in Determination of Misconceptions about Electromagnetic Field-
Magnetism Contents and Effects of Video-Based Experiments on Students' Achievement at Distance Learning Course. Procedia-Social and Behavioral Sciences, 55, 155-160.

Yolanda, Y. (2017). Remediasi miskonsepsi kinematika gerak lurus dengan pendekatan STAD. SPEJ (Science and Physic Education Journal), 1(1), 3948.

Zulvita, R., \& Halim, A. (2017). Identifikasi dan remediasi miskonsepsi konsep hukum newton dengan menggunakan metode eksperimen di man darussalam. Jurnal Ilmiah Mahasiswa Pendidikan Fisika, 2(1), 128-134.

ConflictofInterestStatement:Theauthorsdeclarethat theresearch was conducted in the absence of any commercial or financial relationships that could be construed as a potential conflict of interest.

Copyright $(02021$ Noly Shofiyah. This is an open-access article distributed under the terms of the Creative Commons Attribution License (CCBY). The use, dis- tribution or reproduction in other forums is permitted, provided the original author(s) and the copyright owner(s) are credited and that the original publication in this jour-nal is cited, in accordance with accepted academic practice. No use, distribution or reproduction is permitted which does not comply with these terms. 


\section{LIST OF TABLES}

1 Kemungkinan Pola Jawaban Siswa dan Kategorinya

2 Hasil Tes Diagnostik Two-tier Materi Kemagnetan 
TABLE1/Kemungkinan Pola Jawaban Siswa dan Kategorinya, (Utami, Agung, \& Bahriah, 2017)

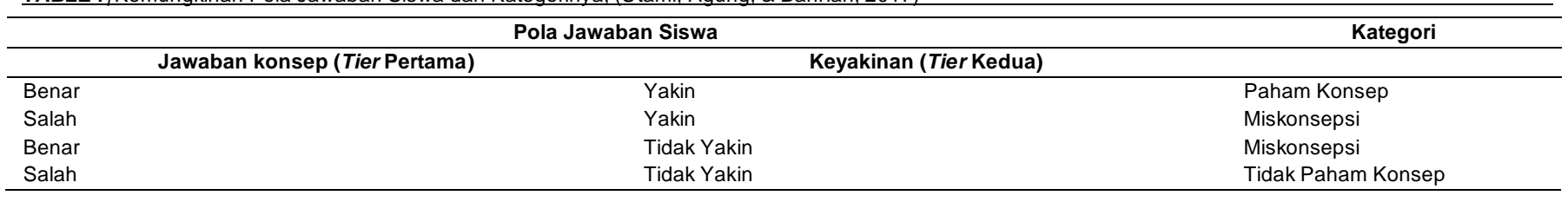


$\underline{\underline{\text { TABLE2/Hasil Tes Diagnostik Two-tier Materi Kemagnetan }}}$

\begin{tabular}{|c|c|c|c|c|}
\hline \multirow{2}{*}{ Indikator } & \multirow{2}{*}{ Nomor Soal } & \multicolumn{3}{|c|}{ Kategori } \\
\hline & & Paham Konsep & Miskonsepsi & Tidak Paham Konsep \\
\hline 1. Menjelaskan pengertian magnet; & 1 & $19 \%$ & $66,8 \%$ & $14,2 \%$ \\
\hline 2. Menjelaskan sifat-sifat magnet; & 2 & $9,5 \%$ & $71,5 \%$ & $19 \%$ \\
\hline 3. Menjelaskan sifat-sifat magnet bahan; & 3,4 , dan 5 & $33,4 \%$ & $34,9 \%$ & $31,7 \%$ \\
\hline 5. Menjelaskan konsep kemagnetan bumi; & 9 dan 10 & $9,5 \%$ & $64,3 \%$ & $26,2 \%$ \\
\hline $\begin{array}{l}\text { 6. Menjelaskan konsep induksi } \\
\text { elektromagnetik; }\end{array}$ & 11 & $14,2 \%$ & $71,6 \%$ & $14,2 \%$ \\
\hline
\end{tabular}




\section{LIST OF FIGURES}

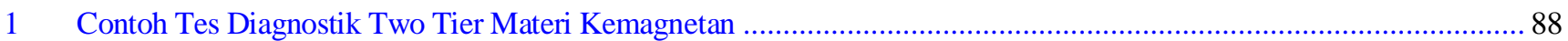


Contoh Pertanyaan 1

1.1 Menurut Anda, apakah yang dimaksud dengan magnet itu?

a. Suatu besi jenis tertentu yang dapat menarik benda-benda yang terbuat dari logam jenis tertentu

b. Syatu besi yang dapat menarik benda-benda yang terbuat dari logam tertentu

c. Suatu jenis logam tertentu yang dapat menarik benda-benda yang terbuat dari besi

d. Suatu jenis logam yang dapat menarik benda-benda yang terbuat dari logam tertentu

1.2 Apakah Anda yakin dengan jawaban Anda?

a. Yakin

b. Tidak Yakin

Contoh Rertanyaan 2

1.1 Perhatikan gambar di bawah ini:

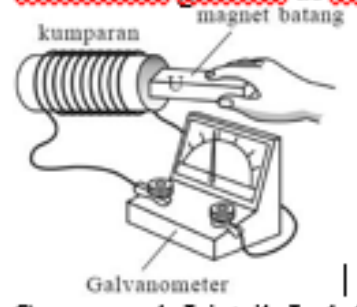

Gaya gerak Listrik Induksi (GGL Induksi) dapat ditimbulkan jika

a. Magnet diluar kumparan

b. Magnet keluar masule kumparan

c. Magnet di dalam kumparan

d. Jarum galvanometer bergerak

1.2 Apakah Anda yakin dengan jaxxaban Anda?

a. Yakin

b. Tidak Yakin

FIGURE 1 / Contoh Tes Diagnostik Two Tier Materi Kemagnetan 